\title{
'We are running for a living': Work, leisure and speculative accumulation in an underground numbers lottery in Johannesburg ${ }^{i}$
}

\author{
Detlev Krige \\ University of Pretoria (pfdkrige @ telkomsa.net)
}

\section{Introduction: the informal and occult in the economy}

Over the past years the informal economy has once again taken centre stage in debates regarding the relationship between states and markets on the one hand and the global economy in distributing wealth in national economies and in regulating and/or supporting formal sectors of the national economy on the other (MacGaffey 1991; Portes 1994; Rogerson 1996). Earlier debates were concerned with whether forms of 'petty commodity production' in the informal economy are benign, exploitative or productive, whether it could be a possible solution to chronic unemployment and whether the informal economy is an independent sector of entrepreneurs or a subordinate segment of survivalist actors. Recent research has situated informal economic activities and the informalisation of labour and work under neoliberal capitalism in a more global context. In this literature, ethnographically-informed analyses have articulated the voices of those who operate outside the documented and sanctioned sectors of national economies and have analysed the life-worlds of actors and social groups engaging in such economic activities (MacGaffey et al 2000; Bourgois 1995; Stoller 2002). This article aims to make a contribution to this approach in the southern African literature, continuing Marcus' call for breaching the distance between economic and cultural analyses (Marcus 1990, cf. Wolcott 1997).

Anthropologists Jean and John Comaroff proffered strong arguments about the emergence of particular forms of translocal economic processes and practices in contemporary postcolonial and postrevolutionary societies, notably South Africa and former Soviet states. These societies all have newly constituted democratic regimes which embraced a doctrine of free market economics coupled with a rights-based political discourse. Having risen above the clutches of apartheid colonialism and Soviet communism respectively, millennial capitalism presented itself to these nations as "a gospel of salvation; a capitalism that, if rightly harnessed, is invested with the capacity wholly to transform the universe of the marginalized and disempowered" (Comaroff and Comaroff 2000:2). The Comaroffs observed the rise of 'occult economies' among these spatially distant societies: the intensification of reports on get-rich schemes, the popularity of prosperity gospels and new churches, the changing fortunes of gambling, the seemingly explosion in witchcraft accusations, and rumours of trafficking in human organs. They suggested that these 'occult' forms of economic processes and practices not only combine a potent mix of 'magical technologies and mysterious modes of accumulation', but had indeed become ordinary- the occult has become part and parcel of mainstream economic practice (Comaroff \& Comaroff 1999a:281-2). Their contribution was to try and 'dissect millennial capitalism and the culture(s) of neoliberalism: to explore their impact on the ways in which people at different coordinates on the global map come to define the nature of value, grapple with the forces of production and reproduction, inhabit moral economies, and engage in political action' (1999b:309).

Sally Falk Moore raised questions regarding causality in their arguments, quantitative escalations between local-level occurrences and global-level explanations, and the methodology employed by the Comaroffs (1999a). Moore (1999:306) protested that the 'idea that the contemporary 
configuration of these phenomena is attributable to present forms of capitalism is to turn contemporaneity into cause, general context into particular explanation. Such is not a falsifiable proposition. Nor is it a provable proposition. It suggests possibilities. It does not demonstrate them". While the notion of 'occult economies' do not present us with clear hypotheses which we can test empirically, we can add and perhaps retract from the notion by offering detailed, historical ethnographies of get-rich schemes, new churches, lotteries, witchcraft accusations, and trafficking in human organs. My aim is to engage the abovementioned discussion with reference to ethnographic research conducted on the popular economies of Black Johannesburg and Soweto. This article is not explicitly comparative and theoretical - I focus on the organisation and meanings of only one informal lottery in a single, albeit important, corner of the postrevolutionary global order. This underground lottery - called fahfee - is of Chinese origin and has been played in many urban townships, suburbs, industrial centres and rural towns of South Africa for the past century. I first pay attention to the local-level sociological organisation of the lottery and the meaning it has for older and younger participants of different social classes, before situating these within the context of a larger political economy that evidently is part of the translocal processes generated by neoliberal and financial capitalism. In this way I try and "tie translocal processes to local events" (Comaroff \& Comaroff 1999a:287).

Speculative accumulation (making money through gambling and conceiving of gambling as 'business) is not a recent phenomenon for those operating at the margins of the state-sanctioned formal economy: for many urban black South Africans, speculative practices involving 'making money out of nothing' is neither new nor characteristic only of a contemporary zeitgeist. While 'living of gambling was the epitome of immoral accumulation' (Comaroff \& Comaroff 2001:5) for some under apartheid, evidence suggests that, in Johannesburg at least, gambling has for long been regarded as 'business' and as a livelihood strategy for those living at the margins of state and society. The ethnographically-informed analysis of this lottery also illuminates the varying ways in which diverse actors, positioned differently in terms of social class and generation, experience the effects of growing inequality and economic and social uncertainty generated by contemporary neoliberal capitalism in South Africa. As such I concur with Sallaz's remark on Clifford Geertz's famous essay on the Balinese cockfight when he wrote that "we can gain insight into a society's culture through careful ethnographic study of the concrete interpersonal situations in which its members wager, gamble and take risks" (Sallaz 2008:6)

\section{Ethnographic context: the Kliptown bank and Ma Shabalala}

It was just before 12:00 on a Wednesday morning in 2004 and a hired interpreter and I were driving out of one of the predominantly Zulu-speaking hostels in a Sowetan neighbourhood that was a site of bloody clashes between township residents (comrades) and hostel dwellers during the dying years of apartheid. We were there to visit an herbalist who wanted to show us the video of her initiation ceremony as a healer (nyanga). I was keener to learn from her how she was able to better the 'luck' of clients wanting to improve their money-making businesses or help gamblers 'dream better'. The herbalist's office was and old camper given to her by a white client she had once helped, and was parked outside one of the hostel units. A power failure at the hostel - the symbol of the migrant labour system and racial capitalism - cut short our interview and we left to go and interview Ma Shabalala, the head runner at a well-known fahfee bank in Kliptown. Leaving behind the hostel - with its lined tiny hostel rooms now utilised as family units but with no one really knowing for sure the legal rights the households residing there have to these units - 
we made our way by motor car to Beacon Road. The old and impoverished location of Kliptown was abuzz with pedestrians, informal street vendors, taxis, police cars - and construction dust. The then recently launched Johannesburg Blue IQ project - a public-private partnership between the city and business that promised Sowetans an improved taxi rank, adjacent market stalls to the informal street vendors, in addition to the elaborate plans to architecturally commemorate the adoption of the Freedom Charter in 1955 with a conference hall and other tourist-attracting ventures - was a major site of construction. The traffic was still manageable back in 2004, as the drastic increase in the number of motor vehicles on the road - brought on by the consumer-driven economic boom and the availability of cheap credit to the growing black middle class - was not yet in full swing. The advertising billboards which dotted the roads were dominated by financial institutions offering cheap credit, the national lottery promising big winnings and cellular communication companies offering various discounts. A few True Love billboards spoke of HIV/AIDS.

During previous visits and interviews I had learnt that the Chinese banker who owns this particular bank is called Jo. Jo is believed to reside in the old Chinatown section of downtown Johannesburg and he is also the owner of a nearby butchery shop. The bank in Beacon Road, where Ma Shabalala was the chief runner, was played twice a day, at 13:15 and 17:00. This meant that twice a day Jo would 'do a pull' and announce the 'drawing number' and would then compensate punters according to the bets they had placed. Ma Shabalala is the local organiser of the lottery (the head runner) and she conceives of herself as Jo's business partner, given the history of her involvement with Jo and this particular bank. She told me she started this bank with Jo and a shoemaker friend back in 1978 - in fact, it all started with a dream. During 1978, in the aftermath of the Soweto student uprisings, she lost her job at Amalgamated Carpets in Johannesburg. One night, soon afterwards, she had a dream in which her father appeared to her and instructed her to 'go and play the horses'. He was specific and instructed her to bet money on 'double 16'. She did not know anything about horseracing or gambling, so she consulted an old woman who lived in Orlando East. While this woman interpreted her dream for her, another friend helped her with the practical talk of betting 'double 16' on the horses. Listening to the radio the day after having laid her bets, Ma Shabalala learnt that hers were the winning numbers! This was obviously significant. At around the same period, while she was staying in Orlando East, she decided one day to again wager money. Only this time by playing the mysterious yet ever present fahfee - something she had never done before. She placed two bets, one on 'number 5 ' at a bank in Orlando and another on 'number 10' at a bank in central Johannesburg. To her surprise she had picked the winning numbers for both games and had won a considerable amount of cash. Her winnings were so substantial that the Chinese banker could not immediately pay out her winnings in cash. Instead, he offered her the keys to his motor vehicle. She could not drive so she declined his offer. The next day the Chinese banker had brought her the winnings. Amazed by the banker's honesty and bolstered by her belief that 'everything happens for a reason', Ma Shabalala decided there and then to become a fahfee runner, soon thereafter starting the Beacon Road lottery with Jo and becoming the head runner of that bank.

For nearly 30 years since then she had been the head runner and it was with this 'job' as head runner for an illegal numbers lottery, she proudly informed me, that she had built a five-room house amidst the informal shacks along Klipspruit River and had 'put all her children through school'. There are interesting parallels between the narrative structure of her life history and the standard narrative structure of the calling of healers I interviewed. Both narrative structures refer 
to a period of crisis (here the loss of a job and for many healers a period of mental/physical illness), followed by a vision or dream through which the ancestors communicate a message which must be acted upon (learning how to gamble or undergoing training as a healer under a mentor) and the subsequent 'qualification' and practice (as either a healer or a fahfee runner). In more ways that one then, Ma Shabalala had become a city shaman - dreaming her own dreams while interpreting the dreams of others players so they can pick a number that will bring them fortune. Despite the divinatory dimension entailed in being a runner, and despite my questioning her about the lack of productive work that is entailed in operating games of chance (itself underpinned by a labour theory of value), she was adamant in describing her income-generating activities through fahfee as 'a job'.

Ma Shabalala was not ignorant of the moralising debates regarding lotteries and her responsibility as mother and as head of a household. After all, during apartheid most forms of gambling was illegal and the mainstream churches preached against it. She was acutely aware of the flip side of winning money easily: you are just as likely to lose it as easily. So, whereas she was aware that 'money comes easy in fahfee', she admitted that one must be careful because 'fahfee can eat your money'. Over the years she had developed a number of rules of thumb to help her balance the demand of generating money in an unforgiving urban cash economy through earning commission as a runner and directing such monies to purchasing either material necessities or to grow her income by taking risks and punting. For example, she does not wage (play fahfee) with large amounts of money. She also prioritise her spending: 'The most important thing to do is to first buy something for the house which you don't have, like a candle or something, and then if you have something left then you play fahfee and maybe God will bless you'. Her main income, of course, was not from fahfee, but from a monthly state old-age pension grant then worth R740. But the reality was that Ma Shabalala had very little else to do in order to generate some income. And, as was the case with many of the other pensioners and unemployed runners I interviewed, she responded to my naïve questioning about why they play fahfee with the simple yet stark truth that people play fahfee because they are hungry: 'we are running for a living'.

\section{Historical and popular accounts}

The underground numbers lottery has been played around Johannesburg for nearly a century and has always been associated with the South African Chinese community. It remains unclear whether fahfee was introduced by indentured Chinese labourers who worked on the gold mines of the Reef between 1904 and 1910 or whether entrepreneurs and businessmen from today's Guangzhou brought the lottery with them as they came to seek their fortunes in gam saan, which means 'Gold Mountain' in Cantonese (Accone 2006; Yap \& Man 1996). This association is not only historical; all of the neighbourhood banks I researched were being run by Chinese 'bankers'. As the game is whispered to be centrally controlled by the local 'Chinese mafia', and strictly speaking illegal, it came as no surprise that no banker was willing to speak to me. The degree to which individual bankers are linked to a central organisation that may 'fix' the thousands of lottery pulls taking place daily all over the country is unsure. If such an organisation does exist it may play a role in the allocation of new fahfee banks in townships and suburbs, as reports of recent 'turf wars' between established South African-born Chinese bankers and newer immigrants from Taiwan indicate. 
Sources suggest that the lottery has remained remarkably consistent in its social organisation and rules over the past century. In short, punters make use of runners to place wagers of usually small amounts of money on any number(s) between 1 and 36. At set times and established places, between two and six times a day, a banker arrives at the designated 'bank' and announces the winning number of that particular draw. At the time of this research, the banker paid out 28 Rands (R28) for every R1 that was waged on the winning number, of which about $25 \%$ is taken by the runner as commission while the remainder goes to the punter. The American missionary Ray Phillips' description of a fahfee bank existing in Marshall Town in Johannesburg in the 1930s is strikingly similar to how the lottery is being run to this day (Philips 1938:422). He suggested that it was first played at the Cantonese Club in central Johannesburg, and that by the 1930s it was played in the surrounding areas of Vrededorp, Sophiatown, Newclare and Doomfontein (Phillips 1938:218; Changfoot 1982:28). It seems likely that it was played earlier in the 'Cantonese Quarter' of Ferreirastown, later called 'First Chinatown'.

The numbers game seems to have always been very popular, despite an effort by the apartheid era-police to clamp down on the lottery and other games of chance after 1950 (SAP 1952) ${ }^{\mathrm{ii}}$. As far back as the 1950s Longmore could comment that "the game is finding increasing support and seems to have gripped the imagination of thousands of people, particularly Native domestic servants in the suburbs. But it is claimed that there are white, black, Coloured, Christian and Jewish Fah-fee devotees. They are ubiquitous - hawkers, housewives, factory workers, flower sellers, or even a man in uniform, all playing their hunched, day in and day out." Longmore's analysis form part of a white liberal discourse articulated by politicians, religious leaders and researchers who were concerned about the effects of 'native gambling' on urban Africans (Hellman 1940; Phillips 1938; Longmore 1956). The problem of 'native gambling' was associated in these writings - and in similar analyses elsewhere in the British Empire at the time with the assumed breakdown of traditional family structures and patriarchal gender relations, marital instability, a rise in youth delinquency, alcohol abuse, crime and violence. This tradition of scholarly writing, which treats gambling as "inimical to a healthy society" and as fundamentally problematic, sinful and wasteful, dominated earlier analyses (Reith 1999:1-2).

In the South African context, gambling has also been interpreted in political terms. Thus Dugmore $(1990,1993)$ read the lottery - together with the illicit running of 'European liquor' and participation in the Congregational Church - as central to the nature of Coloured political response in Johannesburg to racial oppression before and after 1939. Through participating in these illegal economic institutions and practices, actors could challenge parts of the overarching system of controls the Coloureds community experienced: the regimes of uniformity, discipline and 'rationally meted-out reward' imposed by the capitalist mode of production (Dugmore 1993:153-178). Importantly, Dugmore also saw it as giving expression to local notions of social class. ${ }^{\text {iii }}$ More recently, concomitant with the legalisation of gambling in postapartheid South Africa (cf. Sallaz 2008), the operators of the National Lottery proposed to turn fahfee into a national legalised lottery-type game. ${ }^{\text {iv }}$ Given the underground character of the lottery, and the fact that bankers are unlikely to have licenses to operate these lotteries, little is known about the combined size of these lottery games. Estimates suggest that up to five million black South Africans may play the game on a daily basis ${ }^{\mathrm{v}}$. Research commissioned by the National Lottery estimate, perhaps eagerly so, a daily turnover of about R20 million, thus bolstering their arguments for formalisation and as a source of state revenue. ${ }^{\mathrm{vi}}$ Newspaper reports on this numbers 
lottery in the media generally stress a couple of aspects: it is played by poor, black South Africans, with women dominating the runner corpse.

We know that Chinese migrant communities introduced similar gambling games in societies where they settled all over the world. In Jamaica, for example, a more complex version of fahfee are now regulated and played through the national lottery system, contributing $70 \%$ of the turnover. ${ }^{\text {vii }}$ But the most well-known other example of a 'poor man's roulette' is the lottery called 'Policy' played mainly in African-American communities in the USA and made famous in Malcolm X's autobiography (Light 1977; Drakes 1993; Wolcott 1997). What stands out even in the most recent of formulations (Reith 1999), is the long-standing treatment in western intellectual history of gambling as a leisure activity, as a domain or ritual "strictly demarcated from the everyday world around it" (Reith 1999:1). The Comaroffs concur: "Over a generation, gambling, in its marked forms, has changed moral valence and invaded everyday life across the world." If gambling is said to be removed from the everyday world, can we describe fahfee as a form of gambling? What if there is no neat separation between fahfee and the everyday world? To answer such questions - to describe and analyse local-level economic activities and how these relate to national and translocal processes - we should pay attention to the sociological organisation of these activities as these are shaped by their own dynamics in addition to being shaped by larger political and economic processes. By linking local organisation, the strategies and tactics of players, local notions of class, gender and identity, we can begin to develop a perspective on how the game relates to broader political and economic structures.

\section{Social organisation and rules of a typical neighbourhood bank}

Any 'bank' consists of several actors who need to perform five roles in order for the lottery to function properly: the banker, the head runner, the runners, the puller and the punters. Whereas the role of the banker is always identified with the owner of the bank and his accomplishes, some of the other roles may be performed by one actor roles simultaneously and/or interchangeably. For example, Ma Shabalala acted as the head runner of the Beacon Road bank, but she was also an 'ordinary' runner who carried her own running pouch and who solicited bettings from other players on a daily basis as a way of earning commission on winnings. In addition, she was also a punter as she punted her own money through the running pouch she carried.

The banker, who in all of the games I investigated was said to be of Chinese descent, is called such because he/she owns the bank, together with any other number of banks in the surrounding neighbourhoods. The banker cannot be a runner, or a puller or a punter and thus stands in relation to the players the way a gambling house does to say its card players. While the banker owns a bank, it is locally organised by a head runner who earns a weekly 'pay' from the banker (between R14 and R20 per week). The head runner not only organises the bank's runners, but also reports to the banker on a weekly basis, ensuring that runners collect bets properly, that winnings are paid out to punters, and that some of the more intricate rules of the lottery are followed fairly. The head runner, one informant told me, controls the bank, 'like the captain of a ship'. The puller, who is a runner and acts as a puller for the duration of a week during which she is paid a small fee, has the responsibility of collating all the betting slips and cash and to exchange these with the banker during the 'pull'. The pull takes place at what is known in local argot as the 'bank' or the 'home office'. viii 
Apart from the easily discernible banker, who normally drives around the township and suburbs in a bullet-proof pick-up truck, the runners are the most visible people at any particular 'home office'. They are the men and women who walk the streets of their neighbourhood or suburb carrying their runner bags (isikhawama) soliciting bets from residents and workers. Typically, two pulls that place at any bank per day and it is then when runners congregate at the 'home office' and constitute a community of runners. Just prior to the banker's arrival for the pull, these runners would meet at the home office, clutching their runner bags, in order to organise the bets and the winnings, to write the 'tote', and to talk and discuss the numbers and their players. They may talk about the runs they had made that morning and how they, armed with their pouches and betting schemas, helped individual clients pick numbers to bet on. They would have discussed how they, as 'shamans of the city', would have interpreted the more tricky dreams of certain clients. And the runners would have written down the numbers picked by clients on a printed 'betting slip' and would have provided their clients with a 'receipt' for the monies they had placed with them.

The pull is the climax of every lottery, when money can be earned to 'put bread on the table' or when your fortunes can change ever so slightly. It is when the money that had changed hands this morning and had circulated in and between bags and had been prayed over finds new owners. It is also a vulnerable moment, when the police may pounce on the runners and demand a bribe from the Chinaman. It is duty of the puller to collect all the bags (containing monies and betting slips) from the runners, to place them in the puller's large bag, and to hand this large bag over to the banker at his arrival. The puller is also the one the banker communicates the winning number to, verbally or in the form of a number written on a piece of paper. The puller may then communicate the winning number to the other runners by a system of non-verbal signals that is linked to the symbols every number represent. So as to eliminate any possibilities of cheating, the exchange between the puller and the banker of the winning number and the large bag of betting pouches occur simultaneously and, when possible, in view of the other runners. For every R1 that was bet on the winning number in any bag, the banker returns R28 to that bag (a 50 cents bet on the winning number pays out R14; R2 pays out R36 etc). The runner who owns the bag then claims for herself a commission fee of between R6-8 from every R28 that was paid out in her bag.

\section{Runner strategies, number symbolism and 'being clever'}

The anthropological literature on gambling and number games makes ample reference to card and number picking strategies gamblers employ in the course of their gambling (Drake 1993; Hayano 1982; Light 1977; Malaby 2003; Wolcott 1997). In fahfee, strategies for number picking are closely associated with number symbolism and the interpretation of dreams and everyday events. Strategies for picking numbers by runners and players are also linked to notions of 'being clever' and outsmarting the banker in order to 'eat' him. Indeed, it is exactly because runners believe there is pattern in how the banker selects the winning numbers that they develop extensive strategies for picking numbers. The number symbolism is made possible by a widely shared scheme employed by all the players I interviewed and in the older literature. In this scheme, each of the 36 numbers is linked to several symbols, which seems to be for the most part a random categorisation of types of people (in terms of race, gender, age, class, and occupation), body parts, animals, events such as funerals and deaths, buildings and vehicles. ${ }^{\mathrm{ix}}$ Punters and runners alike employ the number symbolism in a variety of ways in order to construct strategies for picking numbers to wage on. These strategies entail linking number symbols to themes occurring in 
dreams and everyday events. When inexperienced punters are not certain as to which number to pick, or when several themes are remembered from dreams, runners often act as dream interpreters. ${ }^{\mathrm{x}}$

A crucial dynamic on the local level is that no one is exactly sure how the banker picks the winning number. This uncertainty produces the conditions under which runners and punters develop all sorts of strategies to 'beat the bank'. The banker is of course familiar with the number symbolism, so utilising this scheme is one way runners try and guess the banker. This Chinese numbers scheme is another way as this scheme - given that it was developed by Chinese bankers promises insight into the banker's symbolic universe and his strategy for selecting numbers. Runners and punters' talk regarding number-picking strategies are shot through with references to the often-used phrase 'being clever' (dishebile or the noun kleva). In the history of Black Johannesburg, such phrases are common in the local vernaculars and are used to refer to a broad range of tactics and strategies, and sometimes a general inclination of individuals, to try and outsmart any system or person wielding power and influence. These are associated with the smart and suave figure of the city slicker (and even the figure of the tsotsi) that stands opposed to the ignorant and naïve greenhorn (moegoe or bhari), but it has also come to refer to the tactics aimed at avoiding manual labour, undermining police authority, and evading state institutions that are regarded as illegitimate given its historical collusion with race and class exploitation. It is not surprising that under high apartheid (Crankshaw 2005) - when township economies were characterised by exploitation by outsider (often white) businesses, lack of resources, scarce money, limited opportunities for enterprising business people - strategies and talk of hustling and subordination become important to the culture of the informal economy.

Such talk of competition, strategy and even subordination often form part of the situational dynamics of gambling games, irrespective of the broader political and economic context. In the context of fahfee runners and punters spoke in detail about 'being clever' and beating (or 'eating') the Chinaman. One such tactic is to run ('work') simultaneously for more than one banker in the same neighbourhood, thus increasing one's potential income from earnings and commissions. Another is to operate 'two pockets' (called 'hanging on like a lackey' or lenga) which involves waging money obtained from clients not on numbers they had selected but on others. Or, instead of placing all punters' monies in the bag to be given to the banker, keeping some in your pocket hoping that number will not be pulled. At least then if you do not win any commission on your bag, one runner told me, 'you have some money in your pocket'. If you do win, you can use that money to pay the client who placed a bet with you.

The western literature shows how gamblers often overemphasise their skills and experience in gambling settings, effectively denying (and defying) the statistical probabilities which define western definitions of chance. Moreover, the idea of 'chance' is a relatively recent development in western thinking (Reith 1999). The secularisation of chance - that is the emergence of 'chance' as a radically autonomous and an ontological category in its own right from the $17^{\text {th }}$ century onwards and one separate from notions of fate and the gods - was linked to the development of new forms of commerce linked to the development of a system of mercantile capitalism and developments in statistical theory (Reith 1999:14-23). But Reith's account of the emergence of the Age of Chance draws on the writings of those who were not on the margins of society. She does not give an adequate account of popular and unwritten forms of speculation and risk-taking and 'underground notions of chance' which prospered in Braudel's 'underlying' or 'infra-economies' and the 
'shadowy zones of turbulence' that he theorised as being a constitutive part of capitalism (1983:24). What sort of calculations and belief-practices then inform the content of the strategies and tactics of fahfee runners?

\section{The Chinese banker, speculative accumulation and player's agency}

As is often the case with gamblers (Hayano 1982; Malaby 2000; Wolcott 1997), there is little need for punters and runners to construct a logically coherent set of beliefs regarding luck, chance and picking numbers. The rigidly followed rules of this lottery, as well as the situational and organisation dynamics mentioned above, clearly structure runners' and punters' number-picking strategies. Beyond that, interviewees articulated several widely shared belief-practices. Runners avoid any close contact with the banker, especially when on a winning streak, for fear of being 'polluted' or 'doctored' by the banker and 'running out of luck'. Runners can be identified by the runner number written on each runner's pouch so a banker can identity a runner on a winning streak and try and speak to that runner. 'You should not meet the Chinaman like that [in such a situation]", one runner said, as "he will give you a look, or put some medicine in your bag, and you will stop eating him'. Other belief-practices that were mentioned by runners are familiar to players of games of chance: using medicine (muthi) to dream better, praying over money, abstaining from or indulging in sexual intercourse, and so forth. Given the incredible religious diversity that characterises Black Johannesburg it is not surprising that some runners pray to their Christian God while others ask the blessing of their ancestors; many do both. Others just rely, as they say, 'on luck'. xii Then there are those who believe that you make your own luck by working hard: soliciting wages from as many clients as possible and working out elaborate strategies for eating the banker.

Over and above such belief-practices, the figure of the Chinese banker loomed large in our discussions. Not only because he is the banker, but also because he is Chinese. As to his role as the banker, runners were most interested in the mystery of how he picks the winning number - the uncertainty as to how he selects a winning number sets the stage for the elaboration of all sorts of schemes and strategies and runners imagining they can influence how he picks the numbers. For example, one punter was known for standing in front of his house, conspicuously watering the garden just prior to the pull at his local bank. By standing next to the road watering his garden he was hoping to influence the banker who was about to drive past to pick the number linked with the symbol for water - this was of course the number he had placed money on earlier that morning.

This belief-practice, that runners and punters can influence the outcome of the game by accessing the symbolic universe of the banker or by suggesting to him which numbers to pull, is one of the reasons why this lottery remains so popular. And this is so because of the degree of agency players feel they have over the outcome of the game. Manipulating the outcome of the draw is more than a mere technique for hustling or beating an unjust system; it promises access to the very symbolic language of the banker. This may also explain the distrust and scepticism many punters articulate regarding the National Lottery draws which take place every Wednesday and Saturday on national television. With the Lotto, players experience no sense of agency whereas fahfee has all the trappings of a social drama in a face-to-face community (local forms of social control, the gossip, the sharing and interpretation of dreams, and theorising occurrences in everyday life). Moreover, several 'conspiracy theories' were doing the rounds about how the 
Lotto draws were being manipulated by unknown and untrustworthy entities. This is not surprising given the widely held view shared by many black urban residents that the state has never been an impersonal and neutral force which has looked after their interests. This view was reinforced when during one Lotto draw on television the winning numbers appeared on screen before the balls were picked. Furthermore, not only has the abstract state never been an impersonal force in their lives, but the very logic of ancestor veneration implies that your welfare is not based on chance but on the workings of your ancestors who, in theory, should have your (and by implication their) interests at heart. Similarly, fahfee players do not view the outcome of the pull as the result of some impersonal, neutral and random force but they do articulate a limited sense of agency in the context of the game. In games of chance punters usually have very little sense of agency when it comes to affecting the outcome of the draw or the pull (Hayano 1982) and in fafhee this agency was made possible through the belief-practice that runners could influence the banker.

Over and above the fact that he is the banker, the figure of the Chinese banker is of importance because of the historical role that the Chinese have played in the underground economies of Johannesburg. In addition to the role they played in the inner city and African locations and freehold areas as shopkeepers and business people, they were forced to become middle men in several underground economies due to the barriers that kept them from participating in the formal economy. Some Chinese store-keepers kept "bucket-shops" through which poorer sections of the white community waged money (City of Johannesburg 1943:10) while they provided Africans in Sophiatown with illegal guns (Mattera 1987). Some business owners had to turn to running the numbers game after the destruction of Sophiatown and the introduction of apartheid, under which they were classified as 'coloured' (Changfoot 1982:25-26). With the Liquor Amendment Act of 1961, which passing permitted 'Coloured' and 'Asiatics' to buy 'European liquor', the Chinese did a "flourishing business in bootlegging to the Blacks, profiting by diluting all hard liquor". Prior to this Act, Chinese had to give money to Whites in order to obtain liquor but when they became eligible for buying liquor, they in turn became sellers of liquor to Africans. The role of Chinese and Indian communities as middle men in various underground economies remains evident today in some of the slang terms used to refer to for example fake goods (fong kong) and loaded or false dice (imbombayi).

Views about the potential dangerousness of the Chinese banker (Mattera 1987:54) were offset by the often-expressed and even romanticised trustworthiness that existed between runners and 'their' Chinese banker. For example, Chinese bankers were so enmeshed in local livelihood strategies and trusted to such an extent that they were not harmed during the 1976 riots in Soweto, even though it was very dangerous for outsiders to enter the townships (Mzamane 1982:99). Such positive views were complemented by talk about the meticulous manner in which the Chinese bankers did their work and how it was inconceivable that they would try and cheat runners. ${ }^{\text {xii }}$ Despite the prohibition against gambling under apartheid, Sowetan policemen turned a blind eye to the lottery. There were times when they would approach the banker politely for a small bribe (ntjotjo) for 'looking the other way' but even then the banker was under no obligation to give them anything. This respect for the banker stems not only from his role as employer and entrepreneur in the community, but also from his status as fellow sufferer under apartheid: 'The Chinaman is part of life in ikasi and as such he is respected', one runner commented; "They used to live next to us black people in Kofifi [Sophiatown], and people became familiar with the Chinaman and fahfee. They also suffered under apartheid'. The Chinese banker's outsider status 
and his ability to 'work well with money' also seem integral to local calculations of trustworthiness and the dynamics of speculative accumulation.

\section{The chancing meaning of fahfee: History, gender and social class dynamics}

As much as fahfee provide players and runners with an income generating activity, and with an opportunity to connect to the underground's 'wheels of commerce and finance', it also crystallises local formulations of work and leisure and social class. It allows the observer to track the changing meanings fahfee holds for participants over time. In her response to the Comaroffs, Sally Falk Moore (1999:306) asked what counted as evidence in their arguments: "The evidence necessary for cause and effect arguments requires attention to sequences overtime... What is the place of history in this story?" Moore's critique led me to compare the contemporary meaning of fahfee with both earlier literature on the lottery and the recollections of contemporary players regarding its meaning a generation ago. While contemporary runners' recollections of an earlier time may be infused with a contemporary sense of 'nostalgia for apartheid' (Kynoch 2003), they do provide us with an important view that illuminates the relationship between the lottery, the class and gender profile of the runner corpse, and changes in the political economy.

The majority of the runners I encountered at the various neighbourhood banks I researched are unemployed women who belong to a growing urban underclass. Few of them have any secondary or tertiary education or training. Given the demands of an increasingly skills-based economy, few of them will ever (again) find secure employment in the formal labour market. Some of them are running small businesses from their shacks or backrooms, including selling liquor, vegetables, paraffin, sexual services and so forth. Soliciting bets from players and earning commission on winnings is only one in a range of income-generating strategies. Their main sources of income are renting out backrooms if they are the owner of a former council-owned property, monetary contributions from boyfriends and state social security (especially the R140 child care grants). Pensioners from poor households who are runners rely on monthly old-age grants. Those few runners who were willing to answer my questions about their income suggested that their monthly income from the lottery ranged between R50 and R500, indicating the extreme uncertainty of supplementing their income this way. These runners consistently perceived of their running and punting as 'work'; they were literally 'running for a living'. This category of runners spoke of the economic hardships of 'trying to make something' by being a runner, of 'putting food on the table' and securing money for their grandchildren or children's school fees. Very few of this class of runners referred to the thrill of punting. But they also did not separate their 'work' from other concerns, whether social or religious. Thus fahfee also provided them with an avenue through which to articulate a working class sense of respectability outside the church groups, savings clubs and other forms of association to which they could not afford to belong. Through their skill as city shamans interpreting the dreams of middle class players according to their intimate knowledge of number symbolism and acute observational skills, they could differentiate themselves from those unemployed who just 'sit at home, doing nothing and turning mad'. By walking the streets for money as they were collecting wages, acting as brokers between Chinese bankers and middle class players, they could even articulate and practice an ethic of 'hard work'.

Another category of runners and punters consisted of a different social class: employed men and women and pensioners from 'middle class' township families who rarely showed their faces at the local neighbourhood bank. They would be the clients of the abovementioned runners or would 
own their own runner bags but would not use it to walk the streets to collect bettings. Instead, they would send children or grandchildren to drop off and collect their runner bags at the neighbourhood bank after school. These middle class men and women were often members of the local Methodist or Anglican Church and would be reluctant to associate themselves in public with an illegal lottery-type game. They would at times leave an entire week's worth of bettings with 'their runner' and would typically wage larger amounts of money. Often, also, they would wage at their places of work, where the anonymity of the workplace environment allow them greater space to gamble without the forms of social control evident in a residential neighbourhood. They spoke to me about fahfee in terms of gambling and risk-taking and experiencing the thrill of winning. This was different from how contemporary runners from the underclass talked about fahfee. But it was similar to the recollections of residents and players about the meaning of the lottery as it was played a generation or more ago.

When asked to reflect on the numbers lottery as it was played by their parents and when they themselves were younger, runners and players spoke of how fahfee used to structure much of their mothers' leisure time. They narrated stories of how a few women of the neighbourhood would get together and start running for a bank as a leisure-time activity. Back then the runner corpse was dominated by women, as husbands and father and brothers were likely to have been working. During the 1960s and 1970s, South Africa's economy experienced substantial growth in manufacturing and construction, which meant expanding employment opportunities while foreign investment flowed into South Africa (Posel 1991:249). The growth in relatively stable urban employment associated with the boom was bolstered by the state's more aggressive application of influx control and state investment in the homelands (Posel 1991:252). The rapid economic growth, coupled with state interventions (tightened influx control and the Urban Labour Preference Policy) meant virtually full adult employment in Johannesburg during the 1960s. For those who were prepared to do unskilled and semi-skilled work for poor wages, there was employment aplenty (Glaser 2000:98, 126). In this context of near full employment for African men, women had the opportunity to experiment with leisure. Residents recalled how 'home offices' in the townships became spaces at which women would meet fellow runners and developed social networks and friendships outside of existing kin, neighbour and church networks. In the aftermath of forced removals and relocations, such banks facilitated social interaction and the creation of new senses of community in the newly constructed areas of Soweto. Informants recounted how runners would cement the friendship bonds between them by starting a savings club or burial society. Given that the political economy of apartheid designated males as the main breadwinners of households and beneficiaries of public housing, and were unlikely to disclose their income to their partners (Kramer 1975), fahfee also provided female runners with an opportunity to earn money independently from their husbands (Bozzoli 1991). Re-investing their winnings in a collective savings or burial association made it difficult for husbands to lay claim to these earnings while also serving as a form of social security. In short, during the 1960s and 1970s the numbers lottery was played by township women who were married but who were not formally employed. It was a social institution with economic benefits: women who had spare time at hand could socialise with friends and neighbours whilst making some money independently from their husbands.

These recollections differ markedly from the views aired by younger township residents and those who now constitute the majority of the runners' corpse: unemployed men and women who are desperately seeking to earn a few cents in the growing informal sector. In the desperate eyes of 
these players, fahfee is an economic institution. Younger residents I interviewed also associate fahfee with the urban underclass that had developed in Black Johannesburg with the rapid urbanisation that accompanied the falling apart of influx control in the 1980s. While this urban class has its roots in the changes in the political economy of Johannesburg since the mid 1980s, the increase in social inequality between the new black middle class and the underclass has been exacerbated by the post-apartheid state's trajectory of jobless economic growth (Seekings \& Nattrass 2000; Bond 2007). Combined with continuing urbanisation and migration (Posel 2006), the availability of cheap and undocumented labour, and the informalisation of work and labour (Benjamin 2008), many of the underclass will never work in the formal sector again. If we couple these conditions with the existing low levels of financial literacy that exists in South Africa ${ }^{\text {xiv }}$ as well as a weak history of financial consumer activism with a well-developed financial system known for its monopolistic behaviour, then it is not surprising that fahfee remain an important site of speculative accommodation for those who remain outside the margins of formal economic employment.

\section{Are the occult economies new?}

Several positive interpretations of illegal lotteries have been offered over the years. Dugmore argued that fahfee served as a popular method of income redistribution - in addition to offering limited employment opportunities - in as far as a lot of the money staked was actually returned to individuals within the community (1993:166-7). He suggested we should place it on par with institutions such as Christmas clubs and rotating savings and credit associations. Light (1977) made a similar argument about 'Policy' in African-American neighbourhoods suggesting that the frequency of wagering and the decades-long perseverance of numbers gamblers effectively provide an average player with 1,300 trials. In a decade of gambling at this rate, a gambler confidently can expect to hit at least once (for $\$ 550$ ) against his total investment of $\$ 1,300$. Viewed from a decade's perspective, the expected return of a numbers gambling career approaches the expected value of the game (Light 1997:896-897). Wolcott argued that numbers gambling in American cities should be seen as part of a "burgeoning urban economy that helped many African-American entrepreneurs survive the ravages of the Great Depression, and created a vibrant subculture that was perceived as 'pathological' only by most cynical outsiders" (1997:49). Not only did numbers gambling provide a space for African-American economic nationalism, but this aspect of the informal economy also bolstered a sector of the formal economy. Yet, it is more difficult to make the same argument with respect to fahfee. Whereas the owners of the banks in the USA were members of the very communities if not the same social class in which the games operated, this is not true for the townships and factories in South Africa. With the exception perhaps of the older communities of Kliptown and the Western Areas before their destruction, Chinese bankers were typically not an integral part of township communities. While the bankers described by Wolcott (1997), Drake (1945) and Light (1977) hailed from the community and reinvested their profits in these communities, Chinese bankers did not involve themselves in the upliftment of township communities. They did provide for precarious income-generating strategies through the numbers lottery, and other employment opportunities, but their gambling profits were not returned to the townships.

Like Dugmore (1993:163), I found that fahfee do provide a space for the expression of notions of social class. Moreover, as class inequality has widened and conditions in the labour market changed, the meaning of the game has changed over time. Today it is less associated with leisure 
and social networking than with actors in the urban underclass trying to earn an income through ways that seem integral to how financial capitalism works: 'making money with money'. The lottery remains popular because it is embedded in communities and neighbourhoods, unlike the state-run lottery. It also refuses to separate the social form the economic from the religious but brings all of these domains together by focusing them into a number with a potential windfall. Recent ethnographic work done by Sallaz (2008) suggests that the objectivities associated with playing card games in a South African casino are characterised by a 'denial of any sort of control over outcomes' (2008:11). Sallaz argues that the meaning of gambling in South Africa has changed with the legalisation of mass gambling, effectively displacing pre-existing forms of gambling structured along interpersonal ties. Gambling games are now defined in terms of roles that are institutionally defined (especially that of worker and customer) to such an extent that 'the economic aspect of gambling displaces the social in post-colonial South Africa'. Arguably, for many urban township dwellers, there never has been a separation between the economic and social aspects of participating in fahfee.

The interrelatedness of what have become, materially or ideologically, separate spheres in many northern, industrialised societies, does not ring true for the experiences of the urban underclass. An important part of the Comaroffs' argument is their narrative about the 'changing fortunes of gambling': under the strict moral regime of apartheid rule gambling was treated by both the then dominant Protestant public culture and a conservative populist morality as a 'pariah practice'; as the epitome of immoral accumulation. While gambling was then 'placed outside the domain of work and earning', 'between virtue and transgression' is has today become mainstream (Comaroff $\&$ Comaroff 2000). That may have been the case of gambling in the public culture, but for poor and working class residents gambling has always been an income-generating activity and a form of 'business' (Hellman 1940; Phillips 1938; Longmore 1956). It was not only among Africans that games of chance and gambling activities were regarded as 'business'. In a 1943 survey conducted by the City of Johannesburg's Social Welfare Department on dog-racing among poor (white) communities in Johannesburg is was reported that "gambling at dog racing in Fordsburg is regarded as a business or means of livelihood, and thus although it may have a detrimental effect on their lives, they would not state that that was so" (1943:10). The fact that contemporary fahfee runners - 'those at the nether end of the planetary distribution of wealth' (Comaroff \& Comaroff 2000:282) - describe their participation in an illegal lottery enmeshed in dreams and magical beliefs as 'work' should not come as a surprise as these domains had never been constituted ideologically as completely separate.

At the same time runners do emulate discourses of the formal economy: runners speak about running as a form of employment, complete with weekly 'pay', 'commissions' and the language of corporate financial institutions and state bureaucracies (e.g. 'banks' and 'home offices' and 'stock exchange'). Is it possible then that finance capitalism has become more like the practices of speculative accumulation in the informal economy rather than the informal economy mimicking the workings of the formal economy? The Comaroffs and others have described how financial risk and newer forms of speculation are increasingly crucial to the growth of finance capitalism: "It has been routinzed in a wide-spread infatuation with, and popular participation in, high-risk dealings in stocks, bonds, and funds whose fortunes are governed largely by chance" (Comaroff \& Comaroff (2000:5). Since the 2007-2009 financial recession brought on by the implosion of the sub-prime housing market in the USA, the behaviour of financial investors are readily described as speculative. But if speculation in money markets are regarded by economists as a form of 
investment and indeed as mainstream practice under finance capitalism (Strange 1997), is there then not an argument to be made (e.g. Light 1977) that fahfee runners and punters' speculation with small amounts over time should be seen as a form of accumulation, albeit not in the formal circuits of financial capitalism? Has speculative accumulation through everyday risk-taking not been part of the economic behaviour of those who operate at the margins of the state in underground and infra-economies? And is it not here, beyond the state, where is located the very money market traders who have inserted speculation into the heart of finance capitalism?

\section{References}

Accone, D. 2006. "Ghost people": Localising the Chinese self in an African context. Asian Studies Review Vol.30, pp.257-272.

Bond, P. 2007. The heart of global apartheid: 'Joburg'. Paper presented at the Centre de Cultura Contemporània de Barcelona, September 2007.

Bonner, P. \& L. Segal. 1998. Soweto: A history. Cape Town: Maskew Miller Longman.

Bourgois, P. 1995. In search of respect. New York: Cambridge University Press.

Bozzoli, B. 1991. Women of Phokeng. Johannesburg: Ravan Press.

Changfoot, L. 1982. A many-coloured South Africa. Ontario: Bonsecours Editions.

Braudel, F. 1983. Civilization and capitalism (translated and revised by S. Reynolds). London:

Collins.

City of Johannesburg. 1943. Survey into the effects of gambling at dog racing in certain of the poorer districts of Johannesburg (undertaken for the Dog Racing Commission). Social Welfare Department. Johannesburg.

Comaroff, J. and J.L. Comaroff. 1999a. 'Occult economies and the violence of abstraction: Notes from the South African postcolony'. American Ethnologist 26(2), 279-303.

Comaroff, J. and J.L. Comaroff. 1999b. 'Response to Moore: Second thoughts'. American

Ethnologist 26(2), 307-309.

Comaroff, J. and J.L. Comaroff. 2000. 'Millennial capitalism: First thoughts on a second coming'.

Public Culture 12(2): 291-343.

Crankshaw, Owen. 2005. Class, race and residence in Black Johannesburg, 1923-1970. Journal of Historical Sociology Vol. 18(4), 353-393.

Drake, St Clair and H. Clayton. 1993 [1945]. Black metropolis. Chicago: University of Chicago

Press.

Dugmore, H.L. 1990. 'Diamond Ladies and a dream of Hell: Fah-fee and the Coloured Working

Class of Johannesburg, 1918-1936'. Paper for African Studies Institute Seminar. University of the Witwatersrand, 12 March.

Dugmore, H.L. 1993. 'Becoming Coloured': Class, culture and segregation in Johannesburg's

Malay Location, 1918-1939. Ph.D. University of the Witwatersrand.

Glaser, C. 2000. Bo-Tsotsi. Oxford: James Currey.

Hayano, D.M. 1982. Poker faces. Berkeley: University of California Press.

Hellmann, E. 1940. Problems of urban Bantu youth. Johannesburg: South African Institute of

Race Relations.

Kramer, J.Y. 1975. Self help in Soweto: Mutual aid societies in a South African city. MA Social

Anthropology, University of Bergen. Norway.

Kynoch, G. 2003. Apartheid nostalgia: Personal security concerns in South African townships.

SA Crime Quarterly No. 5, 7-10. 
Light, I. 1977. 'Numbers gambling among Blacks: A financial institution'. American Sociological Review 42, 892-904.

Longmore, Laura. 1956. 'A study of fah-fee'. South African Journal of Science, 275-282.

MacGaffey, J. 1991. The real economy of Zaire. Philadelphia: University of Pennsylvania Press MacGaffey, J. \& R. Bazenguissa-Ganga. 2000. Congo-Paris. Bloomington: Indiana University Press.

Malaby, T.M. 2003. Gambling life: Dealing. Urbana and Chicago: University of Illinois Press. Marcus, G. E. 1991. 'Once more into the breach between economic and cultural analysis'. In R. Friedland and A. F. Robertson (eds) Beyond the marketplace. New York: Aldine de Gruyter. Materra, D. 1987. Memory is the weapon. Johannesburg: Ravan Press.

Moore, S. F. 1999. 'Reflections on the Comaroff lecture'. American Anthropologist 26(2), 304306.

Morris, A. (ed). 1999. Change and continuity: A survey of Soweto in the late 1990s. Department of Sociology, University of the Witwatersrand. Johannesburg.

Mzamane, M. 1982. The children of Soweto: A Trilogy. Johannesburg: Ravan.

Pauw, B.A. 1962. The second generation. Oxford: Oxford University Press,

Phillips, R.E. 1938. The Bantu in the city. Lovedale: The Lovedale Press.

Portes, A. 1994. 'The informal economy and its paradoxes,' in N. Smelser and R. Swedberg (eds)

The handbook of economic sociology. Princeton: Princeton University Press.

Posel, Deborah. 1991. The making of Apartheid. Oxford: Oxford University Press.

Posel. Dori. 2006. 'Moving on: Patterns of labour migration in post-apartheid South Africa', In

Tienda et al (eds) Africa on the move. Johannesburg: Wits University Press, pp. 217-231.

Reith, Gerda. 1999. The age of chance: Gambling in western culture. London: Routledge.

Rogerson, C. M. 1996. Urban poverty and the informal economy in South Africa's economic heartland. Environment and Urbanization Vol. 8, 167-179.

Sallaz, J. 2008. 'Deep plays: A comparative ethnography of gambling contests in two postcolonies'. Ethnography. Vol 9(1), 5-33.

Seekings, Jeremy and Nicoli Nattrass. 2000. 'Class, distribution and redistribution in postapartheid South Africa'. Transformation Vol. 50, pp, 1-30.

South African Police. 1952. Instructions regarding the investigation of crime and aids to investigation. Pretoria: Government Printer.

Stoller P. 2002. Money has no smell. Chicago: University of Chicago Press.

Strange S. 1997. Casino capitalism. Manchester: Manchester University Press.

Wolcott, V.W. 1997. 'The culture of the informal economy: Number runners in inter-war Black

Detroit'. Radical History Review 69, 46-75.

Yap, M. \& D.L. Man. 1996. Colour, confusion and concessions. The history of the Chinese in

South Africa. Hong Kong: Hong Kong University Press. 
${ }^{\mathrm{i}}$ I appreciate valuable comments made on earlier versions of this article by Deborah James, Andre Czeglédy, Chris de Wet, Modise Machele, Lars Buur and Steffen Jensen. I have also benefited from having presented earlier drafts at seminars at the Wits Institute for Social and Economic Research (WISER) and the Departments of Social Anthropology at the University of Cape Town and Stellenbosch, as well as from the comments of two anonymous reviewers. Fieldwork for this article was made possible by a Doctoral Fellowship held at WISER. Todd Lethata provided valuable assistance and insight during the course of field research into this lottery.

${ }^{\text {ii }}$ See also the following court case material: 'Rex versus N' 1955 (2) SA 647 - Transvaal Provincial Division in front of Judges Ramsbottom and Neser and 'The State versus Mofokeng 1962 (2) SA 56 - Transvaal Provincial Division in front of Judges De Wet and Roberts; 'Rex versus Young 1948 (3) SA 964 - Cape Provincial Division in front of Judge Searle; ‘The State versus Chan' 1962 (1) SA 734 - Transvaal Provincial Division in front of Judges De Wet JP and Roberts.

iii Dugmore (1993:163-178) writes that running and playing fahfee, together with dealing in liquor and doing laundry, was very much frowned upon by an emerging middle-class and a result set working-class Coloureds apart from the Coloured middle class. But for the majority of runners, who were working class women, fahfee played an important role in their sense of a growing common class identity (1993:163).

iv Cf. Ngqwebo, S. 'Fah-fee's number might soon be up'. Sowetan/Sunday World, 9 March 2003; Mofokeng, L. 'Fah-fee can turn dreams into riches'. Sunday Times, 7 May 2003. The Star, 5 March 2003.

${ }^{v}$ The Star, 5 March 2003

${ }^{\text {vi }}$ Cf. Lehihi, M. \& F. Ntshingila. 'Count your chickens: play fah-fee'. Sunday Times (Gauteng News), Sunday 30 March 2003.

${ }^{\text {vii }}$ Cf. Lehihi, M. \& F. Ntshingila. 'Count your chickens: play fah-fee'. Sunday Times (Gauteng News), Sunday 30 March 2003. Edwards, A. 'A game of numbers - Betting, Gaming and Lotteries Commission's role called into question'. The Jamaica Gleaner, November 292002 [URL: http://www.jamaicagleaner.com/gleaner/20021129/business/business1.html].

viii In the former townships it is often the case that the head runner's house or shack serves as the home office, in which case the banker contributes a small amount to the head runner for the use of her premises. The head runner is often the person who had started a particular neighbourhood bank by having approached the banker on one of his daily runs through the township with the aim of convincing him to start a bank with her. The banker would have interviewed her, accompanied her home to establish her residential address and they would then have agreed on the arrangements (her 'pay', betting limits for the bank, time of the pull etc). Once it became known in the neighbourhood that a new fahfee bank had been established, prospective runners would have approached the head runner to purchase a runner's bag and runner's number for R3 or R4.

${ }^{i x}$ Every number has one primary symbol linked to, as well as several secondary ones. Runners and players normally mention only one or two symbols per number and believe these symbols to be linked to ancient Chinese symbolism. The symbolism attached to numbers seems structured in no significant way, even though there are some obvious binaries such as left/right; black/white; small/big; human/animal and internal/external.

${ }^{x}$ Another common strategy for picking numbers is known as the 'partner scheme' or 'Chinese numbers'. Every number between 1 and 36 are linked with another number, so that there are 18 pairs of numbers that are usually played together. Punters also often have lucky numbers, and bet on these in conjunction with their dream numbers. ${ }^{x i}$ Another tactic employed by runners was to 'fix' the betting slips just before they hand them over to the puller by rearranging and spreading the money waged by clients: they use the money waged by their clients to bet on numbers they think will win. This was risky, of course, because if the banker pulls a number that you are supposed to have placed money on for a client, you have to pay the winnings from your pocket. And clients are likely to know which number was pulled: the news of the winning number spreads fast around the neighbourhoods. But often runners take this risk, believing that as 'experts' they stand a better chance of beating the banker because they 'know from experience' which number the banker is likely to pull. And if your clients placed betting money on all the possible 34 numbers, your chances as a runner of earning commission also increases. If this is not the case, runners may spread the bettings they had received so as to try and cover all 34 possible numbers. They do this by either rearranging money waged by their clients, or by filling up the numbers not betted on with their own money.

${ }^{x i i}$ Others noted that players often consult with children about what they have dreamt as children are seen to be carriers of luck.

xiii This stands in stark contrast to existing and escalating xenophobic discourses among township residents regarding the alleged exploitation and drug-dealing of shop owners who are non-South Africans, 'outsiders' and 'foreigners' (amakwere-kwere).

${ }^{\text {xiv }}$ See for example the results of the annual Finscope survey conducted by FinMark Trust and TNS Research Surveys which point out "high levels of misunderstanding - or no knowledge at all - of key financial terms". Cf FinMark Trust 
press release: 'A picture of the financial industry for 2008', January 2009. URL:

http://www.tnsresearchsurveys.co.za/news-cente/pdf/Fin08-Summary-Jan2009.pdf. See also M. Fisher-French, 'Big spenders, small savers', Mail \& Guardian, 28 July 2009. 